\title{
Görme Yetersizliği Olan Öğrencilere Yönelik Geliştirilen Fen Etkinliklerinin Analizi: Madde ve Isı
}

\section{Analysis of Science Activities Developed for Students with Visually Impaired: Matter and Heat}

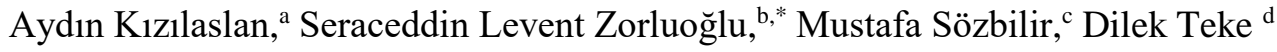 \\ ${ }^{a}$ Dr. Öğr. Üyesi, Ağrı İbrahim Çeçen Üniversitesi, Eğitim Fakültesi, Ağrı/Türkiye \\ ORCID: 0000-0003-3033-9358 \\ b Dr. Öğr. Üyesi, Süleyman Demirel Üniversitesi, Eğitim Fakültesi, Isparta/Türkiye. \\ ORCID: 0000-0002-8958-0579 \\ ${ }^{\mathrm{c}}$ Prof. Dr., Atatürk Üniversitesi, Kazım Karabekir Eğitim Fakültesi, Erzurum/Türkiye. \\ ORCID: 0000-0001-6334-9080 \\ d Doktora Öğrencisi, Atatürk Üniversitesi, Kazım Karabekir Eğitim Fakültesi, Erzurum/Türkiye. \\ ORCID: 0000-0001-7407-2806
}

\section{MAKALE BILGIISI}

\section{Makale Geçmişi:}

Başvuru tarihi: 02 Şubat 2019

Düzeltme tarihi: 03 Nisan 2019

Kabul tarihi: 12 Nisan 2019

\section{Anahtar Kelimeler:}

Fen Eğitimi

Fen Etkinlikleri

Fen Materyalleri

Görme Yetersizliği Olan Öğrenciler
ÖZ

Bu çalışmada görme yetersizliği olan öğrencilerin ihtiyaçları dikkate alınarak hazırlanan etkinlik ve materyallerin analizi yapılmıştır. Çalışmada durum çalışması kullanılmıştır. Çalışma grubu iki kör ve beş az gören öğrenciden oluşmaktadır. Çalışmada veri toplama aracı olarak Fen Etkinlik Gözlem Formu Etkinlik Değerlendirme Boyutu (FEGFEDB) kullanılmıştır. Çalışma üç basamakta gerçekleştirilmiştir: (I) görme yetersizliği olan öğrencilerin 'Madde ve Isı' ünitesine yönelik öğrenme ihtiyaçları tespiti, (II) basamakta ihtiyaçlar dikkate alınarak etkinlik ve materyaller geliştirilmesi ve uygulanması, (III) bu öğretim materyal ve etkinliklerinin değerlendirilmesi. Çalışmadan elde edilen veriler, betimsel analiz ile analizlenmiştir. Veri analiz sonuçlarına göre 'Madde ve Isı' ünitesinde yer alan kavramların öğrencilere etkili bir şekilde öğretilmesi amacıyla hazırlanan etkinliklerin ve etkinlik malzemelerinin öğretim, öğrenme, işlevsellik ve kullanışlılık boyutlarında belirlenen ölçütlerin pek çoğunu sağladığı tespit edilmiştir.

\section{A R T I C LE I N F O}

\section{Article history:}

Received 02 February 2019

Received in revised form 03 April 2019

Accepted 12 April 2019

\section{Keywords:}

Materials

Science Activities

Science Education

Students with Visually Impaired

\section{A B S T R AC T}

In this study, the activities and materials prepared by taking into account the needs of the students with visual impairment were analysed. The case study was used in the study. The study group consisted of two blind and five low vision students. The Science Activity Observation Form Activity Evaluation Dimension (SAFED) was used as the data collection tool. The study was carried out in three steps: (I) the learning needs of the students with visual impairment were determined for the 'Matter and Heat' unit, (II) efficiency and materials were developed, (III) these teaching materials and activities were evaluated. Since the data were analysed by taking into consideration the steps in SAFED. Data was subjected to descriptive analysis. According to the results, it was determined that the activities and activity materials prepared for the purpose of teaching the students in the 'Matter and Heat' unit effectively provided many of the criteria determined teaching, learning, functionality and usability dimensions.

\section{Giriş}

Görme, öğrenmelerimizin temelini oluşturan duyumları ve çevremizdeki uyaranları algılamada en çok ihtiyaç duyduğumuz ve bu sebeple diğer duyularımız içinde önemli yere sahip olan duyudur (Hritcko, 1989). Öğrendiklerimizin \%80-85'ini görme duyusunu kullanarak edindiğimizi düşünürsek, görme duyusunun herhangi bir şekilde

\footnotetext{
* Sorumlu yazar/Corresponding author e-posta: leventzorluoglu@hotmail.com
} 
zedelenmesi ya da tamamen kaybolması durumunda, öğrenme sürecimiz ve günlük yaşam becerilerimizin bu durumdan oldukça olumsuz etkilenebileceği aşikârdır (Cavkaytar ve Diken, 2012). Özellikle erken yaşlarda görme duyusunu yitirmek, kavram gelișiminde ciddi sorunlara neden olabilmektedir (Mann, 2006). Zira görme yetersizliği, çocukluktan itibaren bilişsel ve sosyal gelişimin gerilemesine neden olabilen, öğrenme becerilerinin kazanımını ve günlük yaşam aktivitelerini etkileyerek kişisel yeteneklerin gelişimini güçleştiren, görme gücünün normalden daha düşük olmasıyla ortaya çıkan bir durumdur (Bailey ve Wning, 1994).

Yetersizlik türleri, yetersizlikten etkilenen duyu veya durumlara göre isimlendirilmektedir. Görme duyusunun yetersizlikten etkilenmesi sonucu ortaya çıkan durum da buna bağlı olarak 'görme yetersizliği' olarak nitelendirilmektedir (Kargın, 2012). Görme yetersizliği yasal ve eğitsel olarak iki şekilde açıklanmaktadır. Görme yetersizliğinin yasal tanımı, görmenin ve görme alanının ölçümüne bağlıdır. Yasal tanım, tıp alanında çalışanlar ve diğer ilgililer tarafindan kullanılmaktadır. Bu tanıma göre; tüm düzeltmelerle birlikte, gören gözün olağan görme gücünün onda birine yani 20/200'lük görme keskinliğine ya da daha azına sahip olan ya da görme açısı 20 dereceyi aşmayan bireylere 'kör'; normal görme gücü 20/70 ile 20/200 arasında olan ve yardımcı araçlarla görme gücünden faydalanabilen bireylere ise 'az gören' denilmektedir (Özyürek, 2000; Tuncer, 2005). Eğitsel tanımı ise; görme yetersizliğinden çok ağır derecede etkilenen, mutlaka kabartma alfabeye (Braille) ya da konuşan kitapların kullanılmasına ihtiyaç duyan bireyler 'kör'; büyütücü araçlar yardımıyla ya da büyük puntolu yazılı materyali okuyabilen bireylere ‘az gören’ denir (Gürsel, 2012; Özsoy, Özyürek ve Eripek, 2002).

Eğitimde eşitlik ilkesi gereği gören öğrenciler ile görme engelli öğrencilere uygulanan öğretim programları arasında herhangi bir farklılık bulunmamaktadır. Ancak öğretim programlarındaki bu durum özel eğitime gereksinim duyan görme engelli bireylerin öğrenme ihtiyaçlarını göz ardı eden bir durumdur. Her bireyin bilişsel gelişim süreci genel olarak benzer özelliklere sahip olmasına rağmen, görme engelli bireyler görme duyusu eksikliğinden kaynaklanan sebeplerden dolayı bilişsel gelişim ve öğrenme açısından birçok dezavantaja sahiptirler. Bu nedenle bu dezavantajları ortadan kaldırmak amacıyla dersler işlenirken öğrencilerin görme düzeylerine uygun yöntem, teknik veya stratejiler seçilmeli ve buna uygun olarak tasarlanmış öğretim materyalleri kullanılmalı, bir başka deyişle öğretim programında bazı uyarlamalara gidilmelidir (Levack, Stone ve Bishop, 1991). Bu şekilde düzenlenen uygun öğrenme ortamları ile görme engellilerin bilişsel yeteneklerde ve kavramsal becerilerde gelişme gösterecekleri beklenmektedir (Cavkaytar ve Diken, 2012).

Öğretim süreci içinde görme yetersizliği olan öğrencilerin gören öğrencilerden hem bilişsel açıdan hem de öğretimsel açıdan daha geride kaldıkları en önemli dersler, alan bilgisi gerektiren derslerdir (Kandaz, 2004). Özellikle görsel bilgilerin yoğun olarak kullanıldığı fen bilimleri dersinde görme yetersizliği olan öğrencilerin diğer öğrenciler kadar etkili bir öğrenme gerçekleştiremeyeceği açıktır. Öğrenme sürecinde bireylerin zihinsel faaliyetleri etkin bir şekilde kullanılmakta ve zihinde çeşitli örüntüler kurularak bilgi oluşturulmaktadır (Kalaycı, 2001). Bilginin bireyler tarafından alınması, zihinde o bilgiye ait yapıların oluşması, bireysel ve çevresel düşüncelerle şekillenerek hayata aktarılması gerekir. Bu bağlamda fen eğitimi, süreç içinde edinilen bilgilerin günlük yaşamda uygulanabilir olması ile anlam kazanır. Günlük yaşamda uygulanabilir bilgilerin edinilmesi açısından fen eğitiminin amacı, içinde bulunduğumuz bilgi çağında bilimin farkında olan bir bilgi toplumu oluşturmak ve çağın gerektirdiği bilgi, beceri, tutum ve davranışlara sahip bireyler yetiştirmektir (Topor ve Erin, 2000). Bu amaca bağlı olarak gerçekleştirilen fen eğitimi bireysel ve toplumsal gelişmelere büyük katkılar sağladığı gibi bilimsel gelişmelerin de temelini oluşturur (Ayas, Çepni ve Akdeniz, 1993). Bu nedenle görme yeretsizliğine sahip olsun olmasın eğitim-öğretim sürecine dâhil olan her öğrencinin fen dersine ait bilgi, beceri ve tutumları kazanmış olması gerekir. Bununla beraber görme yetersizliği olan bireylere verilen fen öğretimine yönelik bilgi, beceri ve tutumların kazandırılmasında farklı duyuların kullanımı önemlidir (Rule, Stefanich, Boody ve Peiffer, 2011). Zira görme yetersizliği olan bireyin bir nesneye ilişkin imgesi; dokunma, hissetme ve beden hareketlerinin birleşimine dayanır. Buna "haptik duyum" denir. Görme yetersizliği olan birey, nesneye farklı zamanlarda tekrar tekrar dokunarak elde ettiği duyumları bir araya getirerek haptik bir imge yaratır (Turnbull, Turnbull ve Wehmeyer, 2007). Bunun için nesne parça parça dokunularak incelenir ve nesneye ait kavram geliştirilir. Gören birey ise nesne kavramını gözüyle tarayarak gerçekleştirir. Görme yetersizliği olan birey görsel bir imgeyi tamamen kavrayamazken normal gören bireyler de doğuştan görme yetersizliği olan bir insanın yarattığ haptik bir imgeyi anlamada güçlük çekerler (Zatta ve Pullin, 2004). Görme yetersizliği olan bireyler kendi dünyasını düzenleme ve anlayabilme için mutlaka haptik duyumunu kullanmalıdır ve bunun için (Bishop ve Barraga, 2004; Cox ve Dykes, 2001; Bülbül ve Eryılmaz, 2012; Nepomuceno vd., 2016; Okcu ve Sözbilir, 2019; Özyürek, 1998; Smith ve Kelley, 2007);

- Görme yetersizliği olan çocuk sınıfta eşyaların tümünü elleriyle yoklayarak tanımalıdır. Eşyalar tanıtılırken gerçek adları söylenerek tanıtılmalıdır.

- Zaman zaman çocuğun dokunma duyarlığını geliştirmek için parmak uçlarıyla hissedeceği işler verilmelidir. Örneğin, küçük düğmeler, nohut ve mercimekler kendisine gösterildikten sonra karıştırılır ve daha sonra çocuktan parmak uçlarıyla dokunarak birbirinden ayırması istenir.

- Çevresindeki nesneleri yoklamasına firsat verilmelidir.

- Çocuğa tutabileceği nesneler verilmelidir. Bu sırada tutmakta olduğu nesnenin ne olduğu, neye benzediği ve nasıl kullanıldığı açıklanmalıdır.

- Çocuğun çevresinde bulunan eşyaları iyi tanıyabilmesi için bu eşyaların özellikleri ayrıntılı olarak anlatılmalıdır.

Alan yazında görme yetersizliği olan öğrencilere fen öğretimine yönelik birçok çalışma (Bandyopadhyay ve Rathod, 2017; Bülbül, Garip ve Özdemir, 2017; Hasper vd., 2015; Fantin, Sutton, Daumann ve Fischer, 2016; Kızılaslan, 
2019; Kızılaslan, Sözbilir ve Zorluoğlu, 2019; Okcu ve Sözbilir, 2019) bulunmaktadır. Fakat bu çalıșmalarda bir öğretim yapılmasına rağmen etkinliklerin ya da öğretimin genel olarak bir değerlendirilmesi yapılmamaktadır. Bu çalışmada ise görme yetersizliği olan öğrencilerin ihtiyaçları dikkate alınarak 'Madde ve Isı' ünitesindeki kavramların öğretimine yönelik tasarlanan etkinlikler ve materyallerin öğretim, öğrenme, işlevsellik ve kullanışlılık boyutlarında değerlendirilmesi yapılmıştır. $\mathrm{Bu}$ amaç doğrultusunda aşağıdaki araştırma sorusuna cevap aranmıştır:

- 'Madde ve Isı' ünitesindeki kavramların öğretimine yönelik tasarlanan etkinlikler ve materyallerin öğretim, öğrenme, işlevsellik ve kullanışlılık boyutlarına göre nasıl bir değişim göstermektedir?

\section{Yöntem}

$\mathrm{Bu}$ bölümde çalışmanın araştırma modeli, çalışma grubu, veri toplama aracı, veri analizi, çalışma kapsamında geliştirilen materyaller ve çalışmanın uygulaması hakkında bilgiler verilmektedir.

\subsection{Araştırma Modeli}

Çalışmada durum çalışması kullanılmıştır. Durum çalışmaları, mevcut durumların ya da oluşan durumların daha iyi anlaşılmasını sağlamaktadır (Creswell, 2007). Bu tür çalışmalarda durum ile ilgili olarak araştırmacılar nasıl ve neden sorularını cevaplandırmaya çalışmaktadırlar (Yin, 2013).

Çalışmanın ilk aşamasında görme yetersizliği olan öğrencilerin fen öğrenimi konusundaki ihtiyaçlar belirlenmiştir. İkinci basamakta ise hazırlanan etkinliklerin sınıf ortamında uygulanması gerçekleştirilmiştir. Üçüncü basamakta ise yapılan etkinliklerin Fen Etkinlik Gözlem Formu Etkinlik Değerlendirme Boyutu (FEGFEDB) kullanılarak değerlendirmesi yapılmıştır. Çalışmanın yürütülme basamakları Şekil 1'de gösterilmiştir.

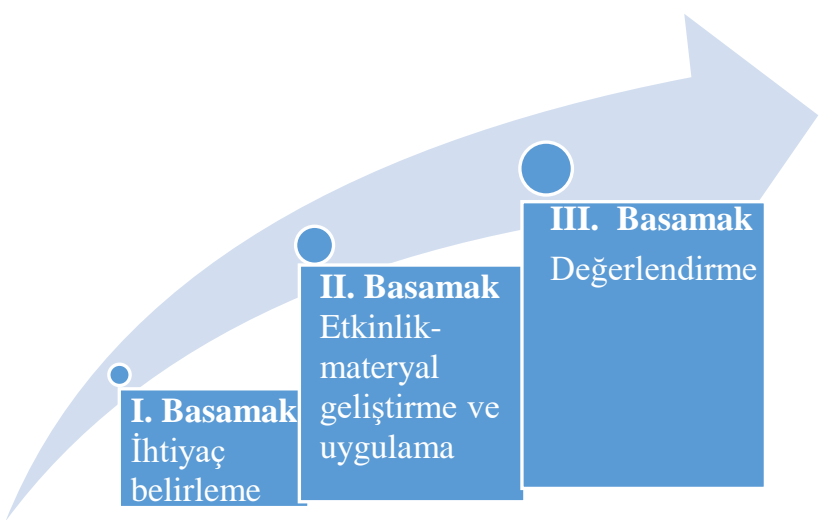

Şekil 1. Çalışmanın yürütülme basamakları

İlk aşamada Madde ve Isı ünitesine ilişkin öğrencilerin kavramsal öğrenme güçlükleri tespit edilmiştir. $\mathrm{Bu}$ amaç doğrultusunda sınıf içinde ilgili ünitenin işlendiği haftalarda video kamera kaydı ile sınıf içi gözlemler ve ünite bittikten sonra ise öğrencilerle yarı-yapılandırılmış görüşmeler yapılmıştır. İkinci aşamada bu belirlenen ihtiyaçlar doğrultusunda etkinlik, etkinlik materyali ve ders modülleri geliştirilmiştir. Örnek bir derse ilişkin modül Ek 1'de yer almaktadır. Az gören ve kör öğrenciler için geliştirilecek materyallerin özellikleri (hitap etmesi gereken duyu, materyalin büyüklüğü, güvenlik boyutu, vb.) az gören öğrenciler için dokümanların satır aralıkları ve punto büyüklükleri kör öğrenci için ise Braille dokümanların içerikleri tasarlanmıştır. Az gören öğrenci için hazırlanan dokümanların Century Gothic yazı tipinde ve en az 18 punto olmasına özen gösterilmiştir. Yapılan araştırmaya göre Centruy Gothic ve 18 punto yazı tipi görme yetersizliği olan öğrenciler tarafindan en iyi okunabilir yazı tipi olarak belirlenmiştir (Çakmak, Karakoç, Şafak ve Kan, 2014).

Ders için hazırlanan modüller değerlendirilmek üzere fen eğitimi alanında uzman iki uzman görüşüne sunulmuştur. Uzmanlar kılavuzları kapsam, yapı, dil ve görünüş açısından incelemişlerdir. Daha sonra kılavuzlarda yer alan etkinlikleri ders saatlerine göre düzenlemek amacıyla görme engelliler okulundaki fen bilimleri dersi öğretmeninin görüşlerine başvurulmuştur. Uzmanlardan ve öğretmenden alınan görüşler doğrultusunda kılavuzlar yeniden revize edilerek düzenlemiştir.

\section{2. Çalışma Grubu}

Çalışma grubu, Görme Engelliler Ortaokulu 6. sınıfta öğrenim gören iki kör ve beş az gören olmak üzere toplam yedi öğrenciden oluşmaktadır. Tablo 1'e göre öğrencilerin üçü kız, dördü ise erkek öğrencidir. Yaş aralığı 12 ile 15 arasında değişmektedir. İki öğrenci bağımsız hareket için erişim desteği alırken beş öğrenci ise bağımsız hareket için erişim desteğine ihtiyaç duymamaktadır. İki öğrenci okumak için yardımcı materyale ihtiyaç duyarken beşi ise herhangi bir şekilde okumak için yardımcı materyale ihtiyaç duymamaktadır (Tablo 1). Ayrıca öğrencilerin fen öğrenme düzeyleri hemen hemen birbirine yakın oldukları belirlenmiştir.

Tablo 1. Çalışma Grubu

\begin{tabular}{|c|c|c|c|c|c|}
\hline Öğrenciler & Cinsiyet & Yaş & $\begin{array}{l}\text { Görme } \\
\text { Düzeyi }\end{array}$ & $\begin{array}{c}\text { Bağımsız } \\
\text { hareket için } \\
\text { erişim } \\
\text { desteği }\end{array}$ & $\begin{array}{c}\text { Okuma } \\
\text { için } \\
\text { yardımcı } \\
\text { materyal } \\
\text { ihtiyacı }\end{array}$ \\
\hline$\ddot{O}_{1}$ & $\mathrm{~K} 1 \mathrm{Z}$ & 13 & Kör & Alıyor & Yok \\
\hline$\ddot{\mathbf{O}}_{2}$ & $\mathrm{~K} 1 \mathrm{Z}$ & 15 & $\begin{array}{c}\text { Az } \\
\text { gören }\end{array}$ & Almiyor & Var \\
\hline$\ddot{O}_{3}$ & $\mathrm{~K} 1 \mathrm{z}$ & 14 & $\begin{array}{c}\text { Az } \\
\text { gören }\end{array}$ & Almiyor & Var \\
\hline$\ddot{O}_{4}$ & Erkek & 14 & $\begin{array}{c}\mathrm{Az} \\
\text { gören }\end{array}$ & Almiyor & Yok \\
\hline$\ddot{O}_{5}$ & Erkek & 13 & $\begin{array}{c}\text { Az } \\
\text { gören }\end{array}$ & Almiyor & Yok \\
\hline$\ddot{O}_{6}$ & Erkek & 12 & $\begin{array}{c}\text { Az } \\
\text { gören }\end{array}$ & Almiyor & Yok \\
\hline$\ddot{O}_{7}$ & Erkek & 13 & Kör & Aliyor & Yok \\
\hline
\end{tabular}

\subsection{Veri Toplama Araci}

Çalışma kapsamında veri toplamak amacıyla FEGFEDB (Ek 2) alan yazında yer alan etkinlik ve materyal değerlendirme boyutları dikkate alınarak hazırlanmıştır (Bundsgaard ve Hansen, 2011). Buna göre geliştirilen FEGFEDB'de öğretim boyutu, öğrenme boyutu, işlevsellik boyutu ve kullanışlılık boyutunu içeren dört değerlendirme boyutundan oluşmaktadır. Geliştirilen form görme yetersizliği olan bireyler, fen eğitimi, program geliştirme ve hem görme yetersizliği olan bireyler hem de fen eğitimi alanlarında çalışan uzmanlara uzman görüşü amacı ile yollanmıştır. Uzmanlar ilk geliştirilen halin sert ifadeler içerdiğinden dolayı bunları yumuşak sorulara dönüştürmemizi istemiştir. 
Ayrıca kategorilendirilmeden oluşturulan form ile ilgili olarak benzer maddelerin farklı değerlendirme kategorileri altında toplanılması gerektiği uzmanlar tarafından belirtilmiştir. Uzman görüşleri dikkate alınarak Ek 2'de yer alan FEGFEDB kullanılmıştır. Uzman görüşleri dikkate alınarak geliştirilen form, pilot uygulama sonucunda değerlendirilmiş ve formun altına gözlemci notları eklenmesinin uygun olacağ 1 düşünülmüştür. Çünkü öğretim esnasında kategorilerde yer alan soruları tam olarak cevaplamayan ya da cevaplasa bile farklı durumları betimlemede yetersiz kalan sorular olabilmektedir. $\mathrm{Bu}$ gibi durumların engellenmesi ve gözlemcinin objektifliğinin arttırılması amacıyla gözlemci notları bölümü eklenmiştir.

\subsection{Verilerin toplanmas1}

Uygulama esnasında kayıt altına alınan kamera görüntüleri ve sınıf içi gözlemler dikkate alınarak her bir etkinliğe yönelik FEGFEDB değerlendirme boyutları ile ilgili veriler toplanmıştır. Ayrıca çalışmanın güvenirliğinin sağlanması amacıyla ders esnasında kaydedilen videolar bağımsız araştırmacılara ayrı ayrı izletilerek FEGFEDB'yi doldurmaları istenmiştir. En son olarak ortak kararlar doğrultusunda gözlem formu doldurulmuştur.

\subsection{Veri Analizi}

Çalışma verileri betimsel analiz dikkate alınarak analizlenmiștir. Betimsel analizde, önceden belirlenmiş bazı temalara, kategoriler veya kodlar dikkate alınarak betimlemeler yapılmaktadır (Glesne, 2013). Çalışmanın gerçekleşmesi esnasında yapılan sınıf içi gözlemler ve ünitenin işlenmesinden sonra yapılan yarı-yapılandırılmış görüşme neticesinde 'Madde ve Isı' ünitesine ilişkin görme yetersizliği olan öğrencilerin FEGFEDB'de yer alan boyutlar (eğitim ortamı, öğretim, öğrenim ve ölçmedeğerlendirme boyutları) dikkate alındığından dolayı betimsel analiz yapılmıştır.

Her etkinlik geliştirilirken etkinliğin hedeflediği değerlendirme boyutları belirlenmiştir. Etkinliklerin değerlendirme boyutları analiz edilirken 'Evet', 'Hayır' ve 'Kısmen' olmak üzere üç kategoriye göre analiz edilmiştir. Bu hazırlanan etkinlik ve materyaller dersi yürüten öğretmen ve bağımsız araştırmacılar tarafından değerlendirilmiştir.

Her bir etkinliğin kapsadığı konu ve kazanım ayrıntılı olarak Tablo 2'de verilmiştir. Buna göre 1sı iletkeni ve 1sı yalıtkanı konularına ilişkin etkinlikler hazırlanırken yakıtlar konusuna ilişkin uygun etkinlik bulunamamıştır. Toplamda beş etkinlik hazırlanırken bu etkinlikler dört kazanımı kapsamaktadır.
Tablo 2. Ders Bilgi Paketlerinin Analizi

\begin{tabular}{|c|c|c|c|}
\hline $\begin{array}{l}\text { Ders } \\
\text { Bilgi } \\
\text { Paketi } \\
\text { (DBP) }\end{array}$ & Konu & Kazanım & Etkinlik \\
\hline DBP 1 & $\begin{array}{l}\text { Is1 iletkeni ve } \\
\text { Is1 yalıtkanı }\end{array}$ & $\begin{array}{l}\text { 6.6.1.1 Maddeleri, isı } \\
\text { iletimi bakımından } \\
\text { sinıflandırır. }\end{array}$ & $\begin{array}{l}\text { Etkinlik 1: Hangi } \\
\text { kaşık ısıyı daha } \\
\text { az iletir? } \\
\text { Etkinlik 2: Çayı } \\
\text { hangi bardakla } \\
\text { taşımalıyım? }\end{array}$ \\
\hline DBP 2 & $\begin{array}{l}\text { Yalıtım ve } \\
\text { Yalıtım } \\
\text { Malzemeleri }\end{array}$ & $\begin{array}{l}\text { 6.6.1.2.Binalarda } 1 \text { s1 } \\
\text { yalıtımının önemini, } \\
\text { aile ve ülke } \\
\text { ekonomisi ve } \\
\text { kaynakların etkili } \\
\text { kullanımı } \\
\text { bakımından tartışır. } \\
\text { 6.6.1.3.Binalarda } \\
\text { kullanılan 1sı yalıtım } \\
\text { malzemelerinin } \\
\text { seçilme ölçütlerini } \\
\text { belirler. }\end{array}$ & $\begin{array}{l}\text { Etkinlik 3: } \\
\text { Evlerimizde } \\
\text { pencerelerde } \\
\text { neden çift katlı } \\
\text { cam kullanırız? } \\
\text { Etkinlik 4: Hangi } \\
\text { bardak 1sıyı en } \\
\text { çok yalıtır? }\end{array}$ \\
\hline DBP 3 & $\begin{array}{l}\text { Yalıtım ve } \\
\text { Yalıtım } \\
\text { Malzemeleri }\end{array}$ & $\begin{array}{l}\text { 6.6.1.4. Alternatif 1s1 } \\
\text { yalıtım malzemeleri } \\
\text { geliştirir. }\end{array}$ & $\begin{array}{l}\text { Etkinlik 5: } \\
\text { Kavanozdaki } \\
\text { suyu nasıl daha } \\
\text { sicak tutarız? }\end{array}$ \\
\hline DBP 4 & Yakıtlar & 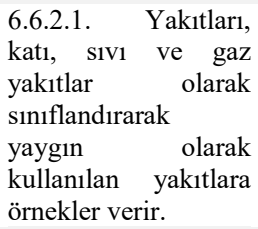 & Etkinlik yok \\
\hline DBP 5 & Yakitlar & $\begin{array}{l}\text { 6.6.2.2 Farklı türdeki } \\
\text { yakıtların 1sı amaçlı } \\
\text { kullanımının, insan } \\
\text { ve çevre üzerine } \\
\text { etkilerini araştırır ve } \\
\text { sunar. }\end{array}$ & Etkinlik yok \\
\hline DBP 6 & Yakitlar & $\begin{array}{l}\text { 6.6.2.3. Soba ve doğal } \\
\text { gaz zehirlenmeleri ile } \\
\text { ilgili } \\
\text { gereken tedbirleri } \\
\text { araştırır ve rapor eder. }\end{array}$ & Etkinlik yok \\
\hline
\end{tabular}

\subsection{Materyaller}

Çalışma kapsamında geliştirilen ve kullanılan materyallerin bir kısmı Şekil 1'de yer almaktadır. Şekil 1'de geliştirilen materyaller öğrencilerin etkinlik sirasında karşılaşabilecekleri kazaların önlenmesi amacıyla bir zemine yerleştirilmiştir. Ayrıca öğrencilerin materyalleri tanıması açısından materyaller öğrencilerin dokunmalarına olanak sağlayacak şekilde dizayn edilmiş ve her bir materyal ile ilgili tanıtım hem Braille yazı hem de büyük puntolu yazı ile yazılmıştır. Ayrıca Ders Bilgi Paketlerinde (DBP) yer alan çalışma yaprakları ve bilgi yapraklarında da hem Braille hem de büyük puntolu yazı bir arada kullanılmıştır. 


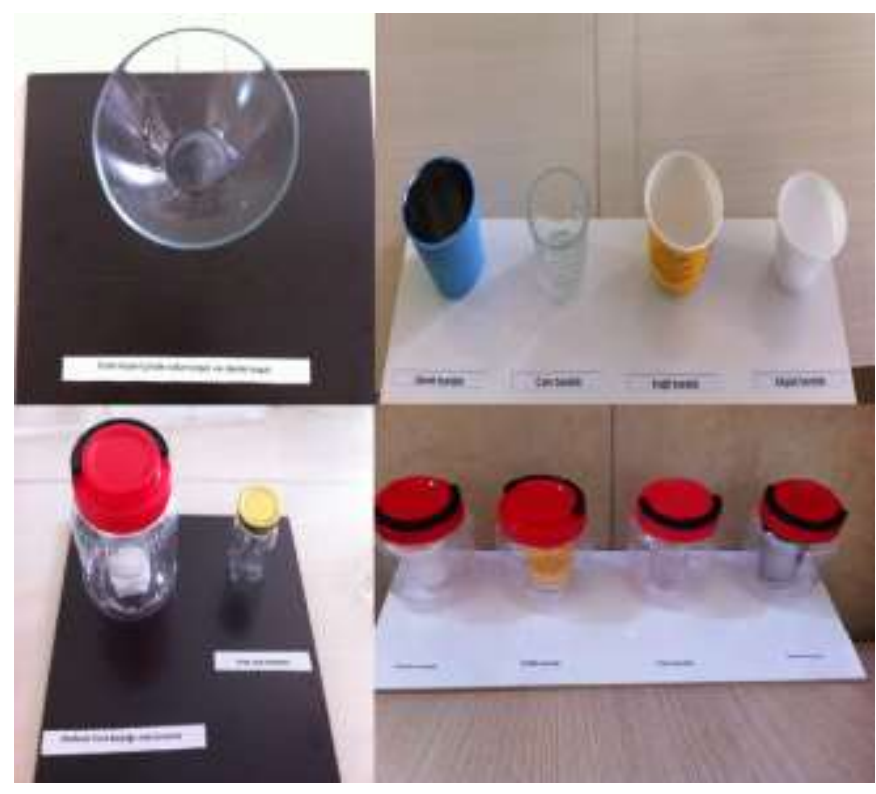

Şekil 1. Geliştirilen Materyaller

\subsection{Uygulama}

Öğretim planında yer alan 6 adet DBP bulunmaktadır. Hazırlanan DBP'lerin uygulaması 2 ders saati olmak üzere toplam 12 ders saati sürmüştür. Uygulama süreci her bir DBP için ayrı ayrı aşağıda açıklanmıştır:

DBP I: Bu bilgi paketinde 6.6.1.1 kazanımına bağlı olarak 1S1 iletkeni ve ısı yalıtkanı kavramları öğrenciye kazandırılmak istenmiştir. Öğrencilerin 1S1 iletkeni ve 1S1 yalıtkanı kavramları çıkarımını yapabilmeleri amacıyla Çalışma Yapră̆ 1 öğrencilere görme yetersizlikleri dikkate alınarak sunulmuş ve etkinliği gerçekleştirebilmeleri için öğrencilere sıcak su bulunan cam kâseye tahta kaşık ve demir kaşık koyularak verilmiştir. Yapacakları etkinlikte öğrencilerin objektif olabilmesi amaciyla 1sı iletiminin el ile kontrolünün sağlanması dışında öğrencilere konuşan termometre kullandırılmıştır. Daha sonra öğrencilere DBP I'de yer alan sorular öğrencilere yöneltilmiştir. Öğretmen bu kısımda öğrencilere beyin firtınası yaptırarak öğrencilerde kavramlarla ilgili bir fikir oluşmasını sağlamıştır. Öğrencilerin zihinlerinde oluşan kavram tanımlarının kesinleşmesi ve tanımlarla ilgili bir genelleme yapabilmeleri amacıyla Çalışma Yaprağ 2 dağıtılmıştır. Çalışma yaprağında yer alan etkinliğin gerçekleştirilmesi amacıyla daha önceden tasarlanan 1sı iletkeni ve isı yalıtkanı bardak düzeneği öğrencilere dağıtılmış, öğrencilerin materyali tanıması sağlanmıştır. Kör öğrencilerin materyal hakkında detaylı bilgi edinebilmeleri için öğretmen tarafindan materyal betimlemesi yapılmıştır. Öğretmen materyal tanıtımından sonra öğrencilere TGA kâğıdı dağıtmış ve "Bu bardakların içine sıcak su koysak sizce hangi bardak en sıcak olur, hangisi en soğuk olur? Bana bardakların sıcaklıklarıyla ilgili tahminde bulunabilir misiniz?" sorusu sorularak öğrenci tahminlerinin TGA kâğıdına yazılması istenmiştir. Yazma işlemi bitince düzenekteki bardaklara sıcak su konulmuş ve öğrencilerden konuşan termometre yardımı ile suların sıcaklıklarını ölçmeleri istenmiş̧ir. Etkinlik sırasında elde ettikleri gözlem verilerini TGA kâğıdına yazmaları istenmiş ve tahminleri ile gözlemleri arasındaki benzerlik veya farklılıkların nedenini açıklamaları istenmiştir. Yapılan etkinliğin öğrenciler tarafindan anlaşılması için Çalışma Yaprağı 2'de yer alan 'Şimdi aşağıdaki soruları cevaplayalım" kısım soruları sorulmuş ve ögrencilerden 1S1 iletkeni ve $1 s ı$ yalıtkanı kavramları tanımı istenmiştir. Her bir öğrenciye söz hakkı verilerek tanımların yapılması sağlanmıştır. En son olarak dersin sonunda öğretmen 1s1 iletkeni ve 1sı yalıtkanı tanımlarını yaparak dersi bitirmiştir.

DBP II: $\mathrm{Bu}$ paket yardımıla 6.6.1.2 ve 6.6.1.3 kazanımlarına bağlı olarak 1S1 yalıtımı ve yalıtım malzemeleri kavramları öğrenciye kazandırılmak istenmiştir. Öğrencilerin 1S1 yalıtımı kavramı ile ilgili çıkarımını yapabilmeleri için derse Çalışma Yaprağı 3 ile başlanılmıştır. Görme yetersizliklerine bağlı oluşabilecek kazaları önlemek amacı ile etkinlikte kullanılacak malzemeler bir düzenek haline getirilmiş ve öğrencilerin önüne sunulmuştur. Düzenek öğretmen tarafindan total görmeyen öğrencilere hem dokundurularak hem de öğretmen tarafindan betimlenerek tanıtılmıştır. Ayrıca az gören öğrencilerin bireysel olarak düzeneği tanımalarına imkân sağlanmıştır. Materyal öğrencilere tanıtıldıktan sonra küçük kavanozlara öğretmen kontrolünde sıcak su konulmuş ve konuşan termometre ile sıcaklıkları ölçülerek kaydedilmiştir. Daha sonra küçük kavanozların kapakları ve büyük kavanozun kapağı kapatılmış ve öğrencilerden 10-15 dakika beklenilmesi istenilmiştir. 10-15 dakikalık süre öğrencilerin kavramlarla etkinliği bütünleştirebilmesi amacıyla bir önceki derste işlenen 1sı iletkeni ve 1sı yalıtkanı kavramlarına yönelik hatırlatmalarla geçirilmiştir. Etkinliğin 1sı yalıtımı kavramı ile ilgili olduğu çıkarımını yapabilmeleri için öğrencilere "Sizce hangi düzenekteki suyun sıcaklığı daha fazla düşer? Neden?" sorusu yöneltilerek tahminde bulunmaları ve hipotez kurmaları istenmiştir. 10-15 dakikalık süre sonunda öğrenciler kavanoz kapaklarını açarak suların sıcaklıklarını ölçmüştür. Öğrenci tahminlere bağlı olarak tahminlerinin doğru olup olmadıkları sorulmuş ve doğruluğu veya yanlışlığı ile ilgili açıklama yapmaları istenmiştir. Öğretmen tarafından bir açıklama yapılmayarak öğrencilere kavramın çıkarımını daha iyi yapabilmeleri için Çalışma Yaprağ 4 dağıtılmıştır. Öğrencilerin etkinliği gerçekleştirebilmesi için öğrencilere "plastik kavanozların içine farklı tür bardaklar yerleştirilmiş" düzenek dağıtılmış ve bu düzeneğinde öğrenciler tarafından tanınması sağlanmıştır. Ayrıca öğretmen düzenek ile ilgili betimleme de yapmışıı. Düzenekteki bardakların içine eşit miktarda sıcak su ve plastik kavanozun içine de eşit miktarda soğuk su konularak kavanozların ağızları kapanmıştır. Daha sonra öğrencilerden hangi bardaktaki suyun daha az ve hangi bardaktaki suyu daha çok soğuyacağı sorusu sorulmuş ve öğrencilerden tahminleri alınarak nedenleri açıklaması isteniştir. En son olarak tahminlerinin doğruluğunu ispatlamaları için kavanozların kapakları açılmış ve her bir bardaktaki su konuşan termometre aracılığıyla ölçülmüştür. Kavramın anlaşılması ve öğrenciler tarafından çıkarım yapılabilmesi amacıyla öğretmen tarafından sıcaklığı çok azalandan en az azalan bardağa doğru sıralama yapmaları ve bu sıralamanın neden böyle olduğunu açıklamaları istenmiştir. Öğrencilere kavramın tanımı bulmaları amacıyla Çalışma Yaprağı 4'te yer alan sorular sorulmuş ve 1S1 
yalıtımı, yalıtım malzemeleri ve yalıtım malzemeleri seçilme ölçütleri ile ilgili video izletilmiştir. Daha sonra öğrencilere 1S1 yalıtımı, yalıtım malzemeleri ve 1sı yalıtımı seçilme ölçütleri kavramlarıyla ilgili sorular sorularak Bilgi Yaprağı 2'de yer alan bilgiler öğrencilere aktarılmıştır.

DBP III: Bu bilgi paketi, yalıtım malzemeleri kavramının öğrencilere kazandırılması amacıyla 6.6.1.4 kazanımına yönelik hazırlanmıştır. Derse 1sı yalıtımı malzemeleri kavramının temelin oluşturan 1sı iletkeni, 1sı yalıtkanı ve 1S1 yalıtımı kavramları sorgulanarak giriş yapılmıştır. Kavramların öğrenciler tarafından pekiştirilmesi için bu kavramlara yönelik örnekler sorulmuş ve öğretmen tarafindan kavramlara yönelik farklı örnekler sunulmuştur. Bir önceki dersi hatırlatma ve DBP III'te işlenecek kavramlarla ilişki kurulması amacıyla yalıtım sınıfa 1sı yalıtım malzemeleri sınıfa getirilerek öğrencilerin deneyim elde etmeleri sağlanmıştır. Isı yalıtım malzemeleri hakkında bilgi edinen öğrencilerden 1S1 yalıtım malzemeleri geliştirmeleri için Çalışma Yaprağı 5 dağıtılmıştır. Daha sonra 1S1 yalıtım malzemeleri geliştirmeleri için büyük plastik kavanoz, küçük cam kavanoz ve Çalışma Yaprağı 5'te yer alan 1sı yalıtım malzemeleri öğrencilere tanıtılarak öğrenci tasarımları için dağıtılmıştır. Öğrencilerin ısı yalıtım malzemelerinden 1sı yalıtımı için büyük plastik kavanoz ile içi sıcak suyla doldurulmuş küçük cam kavanoz arasına dolgu malzemeleri yapması istenmiştir. Cam kavanoz ile plastik kavanoz arası dolgu malzemesi ile doldurulmadan önce sicak suyun sıcaklığı konuşan termometre aracılığıyla ölçülmüş ve dolgu malzemeleri doldurulduktan sonra kavanoz bir kenarda 10-15 dakika bekletilmiştir. Bekleme süresince her bir öğrenciye kullandığı dolgu malzemesi, kullandığ dolgu malzemesinin iletken mi yalıtkan mı olduğu ve bu malzemeleri kullanmasaydı başka hangi malzemeler kullanılabilirdi gibi sorular sorularak tahtaya yazılmıştır. Sürenin bitmesiyle sıcak suyun sıcaklığg tekrar ölçülmüş ve öğrencilerin tasarladığı 1sı yalıtım malzemelerinin hangisinin daha iyi yalıtım malzemesi olduğu tartışılmıştır. Ders sonunda öğrencilere "Haydi, Soruları Cevaplayalım" kısmındaki soruları sorularak derste öğrenilen bilgiler hatırlatılmıştır. Dersin toparlanması ve öğrenilenlerin kalıcılığının arttırılması amacıyla öğrencilere dağıtılan Bilgi Yaprağı 3 az gören öğrencilerden birisine okutularak ders sonlandırılmıştır.

DBP IV: 6.6.2.1 kazanımının öğrencilere kazandırılması amacıyla DBP IV işlenmiştir. Bu paket sayesinde yakıt, yakıt çeşitleri, yenilenebilir ve yenilenemez enerji kaynakları kavramları öğrencilere kazandırılmaya çalışılmıştır. $\mathrm{Bu}$ amaçla dersin başlangıcında hedeften haberdar edilmiştir. Öğrencilerin tanıması için sınıfa getirilen her bir yakıt çeşidi farklı özellikleri ile öğrencilerin deneyimine sunulmuştur. Kavramları öğrencilerin kendilerinin keşfetmesi amacıyla Çalışma Yaprağ 16 dağıtılmış ve çalışma yaprağının sonunda yer alan sorulara öğrencilerin cevap bulması sağlanmıştır. Dersin ikinci kısmında fosil yakıtların çevreye olan etkisi, yenilenebilir ve yenilenemez enerji kaynaklarına giriş amaciyla video izletilmiş ve daha sonra kavramlarla ilgili Çalışma Yaprağı 7 dağıtılmıştır. Az gören öğrencilerden birisine çalışma yaprağı okutulmuştur. Ders süresince öğrenilen bilgiler öğretmen tarafından gerek soru-cevap gerekse öğretmen tanımlamalarıyla özetlenmiştir. Dersin sonunda deve cüce oyunu ile öğrencilerin konuyu anlayıp anlamadıklarını test edilmiştir.

DBP $\mathrm{V}: \mathrm{Bu}$ paketle görme yetersizliği olan öğrencilere 6.6.2.2 kazanımının kazandırılması amaçlanmıştır. Bu amaçla farklı türdeki yakıtların insan ve çevreye etkileri öğrencilere öğretilmeye çalışılmıştır. Ders bir önceki derste öğrenilen kavramların tekrarıyla başlamıştır. Öğretmen öğrencilerin derse ilgisini çekmek için dersin sonunda öğrenileceklerden haberdar etmiştir. Öğrencilerin öğrenilecek bilgiyi kendilerinin çıkarım yaparak bulması için öğretmen sınıfı iki gruba ayırmış ve bir gruba yakıtların olumlu etkileri ile ilgili gazete haberleri verirken diğer gruba olumsuz etkileriyle ilgili gazete haberleri vermiştir. Öğretmen, gruptaki öğrencilerin her birinin haberi okuyarak içeriğini arkadaşlarına anlatmasını istemiştir. Daha sonra yakitlarla ilgili olumlu haberleri okuyan grup öğrencilerinden yakıtların olumlu etkilerini, diğer grup öğrencilerine ise yakıtların olumsuz etkilerini savunmaları istenmiştir. Daha sonra öğrenilen bilgilerin sınıflandırılması için Çalışma Yaprağı 8 dağıtılmış ve haberlerin olumlu ve olumsuz özellikleri dikkate alınarak sinıflandırılması istenmiştir. Konuyu özetleyecek ve öğrenilen bilgilerin hatırlanmasını kolaylaştıracak videolar izletilmiştir. Öğrencilerin öğrenmelerini belirlemek amacıyla ders bilgi paketinin son kisminda yer alan sorular sorulup öğrencilerden cevaplar alınmış ve öğretmen tarafindan yanlış ya da eksik olan cevaplar tamamlanmıştır. Ders bir sonraki derste yapılması gereken görev öğrencilere açıklanarak bitirilmiştir.

DBP VI: Bu pakette soba, doğal gaz zehirlenmelerinde alınması gereken önlemleri içeren 6.6.2.3 kazanımının görme yetersizliği olan öğrencilere kazandırılması amaçlanmıştır. Derse bir önceki ders kavramları hatırlatılarak başlanılmıştır. Daha sonra öğrencilerin konu kavramlarına yönelik hazırbulunuşlukları belirlenmesi amaciyla ders bilgi paketinde yer alan sorular sorulmuştur. Öğrencilerin verdikleri cevapların doğru ya da yanlış olduğu ile ilgili çıkarım yapmalarını ve var olan bilgilerini yapılandırmalarını soba zehirlenmesiyle ilgili video izletilmiş ve soba zehirlenmeleriyle ilgili sorular öğrencilere tekrar yönlendirilmiştir. Öğrencilerin verdiği eksik ya da yanlış cevaplar öğretmen tarafından düzeltilmiş ve soba zehirlenmesi ve alınması gereken önlemleri kısaca özetlemiştir. Öğretmenin doğalgaz zehirlenmesi ve alınması gereken önlemlerle ilgili bir önceki derste vermiş olduğu görev sonucunda topladıkları bilgileri her bir öğrencinin arkadaşlarına sunmasını istemiştir. Öğrencilere doğal gaz zehirlenmesi yaşanmaması için alınması gereken tedbirlerle ilgili bir poster hazırlama ödevi verilmiştir.

\section{Bulgular}

$\mathrm{Bu}$ bölümde çalışmanın birinci basamağında elde edilen ihtiyaçlar ve üçüncü basamağında elde edilen değerlendirmeye yönelik bulgulara yer verilmektedir. 


\section{1. İhtiyaçlar}

Ders içi gözlemler sonucunda görme yetersizliği olan öğrencilere yönelik fen dersleri işlenirken öğrencilerin yetersizlikleri dikkate alınarak fen etkinliklerinin yapılmadığı, dokunsal materyallerin kullanılmadığı, öğrencilerin etkinlikleri gerçekleştirmelerine yönelik yetersizliklerine uygun dokümanların bulunmadığı, etkinlikler yapıldığında güvenlik önlemlerinin alınmadığı ve öğrencilerin görmediğinden dolayı etkinliklere dâhil edilmediği tespit edilmiştir. $\mathrm{Bu}$ tespitler ihtiyaç olarak belirlenmiş ve bu ihtiyaçlar doğrultusunda modül, etkinlik ve etkinlik materyalleri hazırlanırken şu ilkelere dikkat edilmesi gerektiği belirlenmiştir:

1. Hazırlanan materyallerin birden fazla duyuya hitap etmesine önem gösterilmelidir.

2. Az gören öğrenci için hazırlanan materyaller üzerindeki yazıların dekoratif amaçlı süslü yazı yerine Century Gothic yazı tipinde ve en az 18 punto olmalıdır.

3. Öğretim materyalleri ve bilgi amaçlı verilen dokümanlarda üzerinde oluşturulacak kontrast (zıtlık) algılanabilecek şekilde olmalıdır.

4. Öğretim materyalleri hazırlanmasında öğrencinin dokunsal (tactile) duyusu dikkate alınarak materyalin benzerlikleri ve farklılıkları tespit edilebilecek şekilde olmasına özen gösterilmelidir.

5. Hazırlanan materyalde oran-ölçek, bütünlük, vurgu ve ahenk uyumu bir bütün olarak sağlanmalıdır. Yani bir objenin diğer objeye göre uyumu ve bütün ile arasındaki ilişkisine önem verilmelidir.

6. Hazırlanan materyaller öğrencilerin özelliklerine (yaş, zekâ ve geçmiş yaşantıların düzenine) en önemlisi az görenlerin görme düzeylerine uygun olmalıdır.

7. Materyalin anlamlı olması öğrenmeyi kolaylaştırır. Bunun için materyalin öğretimi amaçlanan konu veya kavramla birebir örtüşmesi gerekmektedir.

8. Materyalin bilişsel bilginin yanı sıra duyuşsal ve psikomotor becerileri kazandırmasına önem verilmelidir.

9. Etkinlikle bütünleştirilmiş materyal tasarımında öğrencilerin görme düzeylerine göre heterojen gruplar oluşturulmalıdır.

\subsection{Değerlendirmeye Yönelik Analiz}

Araştırma kapsamına hazırlanan etkinlik ve materyallerin değerlendirilmesi FEGFEDB'e göre analiz edilmiştir. Hazırlanan etkinliklerinden birinin sinifta uygulanmasına ilişkin gözlem verileri Tablo 3'te yer almaktadır. Tablo 4'te ise hazırlanan tüm etkinlik ve materyallerin FEGFEDB'de yer alan öğretim, öğrenme, işlevsellik ve kullanışlılık boyutlarına göre analizi yer almaktadır.
Tablo 3. Üçüncü etkinliğin sınıfta yürütülmesine ilişkin gözlemler

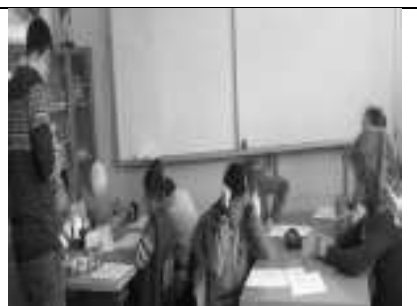
DBP III, yalıtım malzemeleri kavramının öğrencilere kazandırılması amaciyla 6.6 .1 .4 kazanımına yönelik hazırlanmıștır. Derse 1sı yalıtımı malzemeleri kavramının temelin oluşturan 1sı iletkeni, 1sı yalıtkanı ve $1 \mathrm{~S} 1$ yalitımı kavramları sorgulanarak giriş yapılmıştır.

Öğretmen: evet arkadaşlar biz geçen haftaki derslerimizde neler görmüştük? Is1 iletkeni görmüştük, 1S1 yalıtkan1 görmüştük, 1S1 yalıtımını görmüştük değil mi? Şimdi bana 1S1 iletkeninin ne olduğunu kim söyleyebilir?

Ö3: Isıy1 daha iyi iletendir.

Öğretmen. Evet, 1sıyı iyi iletebilen maddelere 1sı iletkeni maddeler denir. Peki, 1sı yalıtkanı nedir?

Ö7: Isıyı iyi iletemeyen maddelere denir tabiki.

Öğretmen: evet doğru 1sıy iyi iletemeyen maddelere 1s1 yalıtkanı maddeler diyoruz. Peki, çocuklar 1sı yalıtımı deyince ne anlıyoruz? Ö2: Isının tutulmasıdır hocam.

Kavramların öğrenciler tarafından pekiştirilmesi için bu kavramlara yönelik örnekler sorulmuş ve öğretmen tarafindan kavramlara yönelik farklı örnekler sunulmuştur. Bir önceki dersi hatırlatma ve DBP

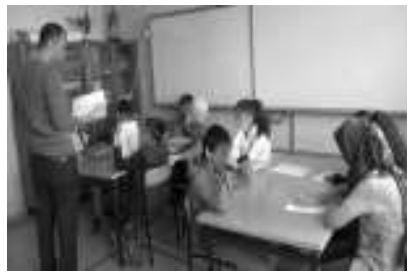
III'te işlenecek kavramlarla ilișki kurulması amacıyla sınıfa 1s yalıtım malzemeleri getirilerek ögrencilerin deneyim elde etmeleri sağlanmıştır.

Öğretmen: Şimdi size yapacağımı etkinliğin kâğıtlarını dağıtacağım ne yapacağınızı okuyun ve anlamaya çalışın.

Öğrencilere 1s1 yalıtım malzemeleri geliştirmeleri için Çalışma Yaprağı 5 dağıtılmıştır. Daha sonra 1s1 yalitim malzemeleri geliştirmeleri için büyük plastik kavanoz, küçük

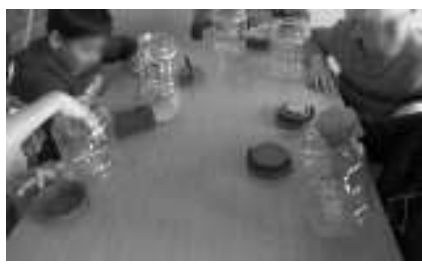
cam kavanoz ve Çalışma Yaprağı 5'te yer alan 1S1 yalıtım malzemeleri öğrencilere tanıtılarak öğrenci tasarımları için dağıtılmıştır.

Öğrencilerin 1S1 yalıtım malzemelerinden 1S1 yalıtımı için büyük plastik kavanoz ile içi sıcak suyla doldurulmuş küçük cam kavanoz arasına dolgu malzemeleri yapması istenmiştir. Cam kavanoz ile plastik kavanoz arası dolgu malzemesi ile doldurulmadan önce sıcak suyun sıcaklığı konuşan termometre aracılığıyla ölçülmüş ve dolgu malzemeleri doldurulduktan sonra kavanoz bir kenarda 10-15 dakika bekletilmiştir.

Bekleme süresince her bir öğrenciye kullandığı dolgu malzemesi,

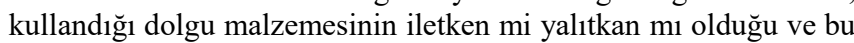
malzemeleri kullanmasaydı başka hangi malzemeler kullanılabilirdi gibi sorular sorularak tahtaya yazılmıştır. Sürenin bitmesiyle sıcak suyun sıcaklığı tekrar ölçülmüş ve öğrencilerin tasarladığı 1sı yalıtım malzemelerinin hangisinin daha iyi yalıtım malzemesi olduğu tartışılmıştır. Ders sonunda öğrencilere "Haydi, Soruları Cevaplayalım" soruları sorularak derste öğrenilen bilgiler

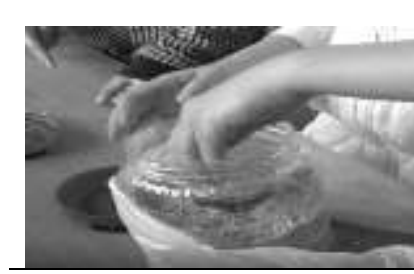
hatırlatılmıştır.

Dersin toparlanması ve öğrenilenlerin kalıcılığının arttırılmasi amaciyla Bilgi Yaprağ 1 3, öğrencilerden birisine okutularak ders sonlandırılmıştır.

Tablo 3 ve Ek 1 dikkate alındığında DBP'lerinin Tablo 4'te yer alan boyutlar dikkate alınarak hazırlandığı kolaylıkla 
belirlenebilmektedir. İhtiyaç aşamasında belirlenen ihtiyaçlar doğrultusunda DBP'lerin ve etkinliklerin düzenlemesinin yapıldığı ve buna bağlı olarak uygulamanın yapıldığ 1 da Tablo 3 ve Tablo 4'e birlikte bakıldığında anlaşılmaktadır.

Tablo 3 incelendiğinde öğretim boyutuna göre derste öğrencilerin ön bilgilerin tespit edilmeye yönelik soru sorulduğu, etkinlik öncesinde etkinliğe yönelik farkındalık oluşturulmaya çalışıldığı, malzeme ve etkinlik tanıtımının yapıldığı, etkinliğin ise konu amacina uygun olduğu; ögrenme boyutuna göre dokunsal, sesli materyaller, Braille ve büyük punto ile yazılmış etkinlik kâğıtlarının kullanılması öğrenme için farklı duyuların aktif edildiğini, günlük hayatta kullanılan malzemeler yoluyla 1sı yalıtım malzemelerinin tasarlanması ise etkinliğin günlük hayattaki olaylar dikkate alınarak hazırlandığg, önceden öğrendiği bilgililerle ilişkili etkinliğin olduğu, öğrencinin aktif katıldığı, kullanılan materyaller sayesinde etkinliğin ilgi çekici olduğu ve etkinliği kolay bir şekilde yapmalarına bağlı olarak hedef grubun bilişsel özelliklerine uygun olduğu; işlevsellik boyutuna göre etkinliklerin kazanımların kazandırılmasına yönelik olduğu, etkinlikte kullanılan düzeneklerin tekrar tekrar kullanılabileceği ve bireysel farklılıkları dikkate alınarak bireysel kullanımları aktif kılabilecek şekilde hazırlandığı; kullanışlılık boyutuna göre uygun zamanlama düzeylerinin belirlendiği, kullanılan malzemelerin ekonomik ve kolay ulaşılabilir düzeyde olduğu ve etkinliklerde öğrenci güvenliklerinin dikkate alındığı görülmektedir.

Tablo 4. Etkinliklerin Değerlendirme Boyutlarına Göre Analizi

\begin{tabular}{|c|c|c|c|c|c|}
\hline & $\begin{array}{c}\text { Etkinlik } \\
1\end{array}$ & $\begin{array}{c}\text { Etkinlik } \\
2\end{array}$ & $\begin{array}{c}\text { Etkinlik } \\
3\end{array}$ & $\begin{array}{c}\text { Etkinlik } \\
4\end{array}$ & $\begin{array}{c}\text { Etkinlik } \\
5\end{array}$ \\
\hline Değerlendirme Boyutları & 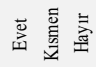 & 总吉营 & 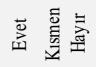 & 总离营 & 总哥言 \\
\hline \multicolumn{6}{|l|}{ Öğretim Boyutu } \\
\hline $\begin{array}{l}\text { Etkinlik başlangıcinda sorulan sorular ön } \\
\text { bilgileri test etmeye uygun mu? }\end{array}$ & $\mathbf{x}$ & $\mathbf{x}$ & $\mathbf{x}$ & $\mathbf{x}$ & $\mathbf{x}$ \\
\hline $\begin{array}{l}\text { Etkinlik önces indeki hazrrlık soruları etkin liğe } \\
\text { iliş kin farkındalık oluş turabiliyor mu? }\end{array}$ & $\mathbf{x}$ & $\mathbf{x}$ & $\mathbf{x}$ & $\mathbf{x}$ & $\mathbf{x}$ \\
\hline $\begin{array}{l}\text { Etkinlik ve kullanılacak malzemelerin tanıtımı } \\
\text { için verilen zaman yeterli mi? }\end{array}$ & $\mathbf{x}$ & $\mathbf{x}$ & $\mathbf{x}$ & $\mathbf{x}$ & $\mathbf{x}$ \\
\hline $\begin{array}{l}\text { Etkinlik planlanan konunun amaciyla uyumlu } \\
\text { mu? }\end{array}$ & $\mathbf{x}$ & $\mathbf{x}$ & $\mathbf{x}$ & $\mathbf{x}$ & $\mathbf{x}$ \\
\hline \multicolumn{6}{|l|}{ Öğrenme Boyutu } \\
\hline $\begin{array}{l}\text { Etkinlik farklı duyularn kullanımina firsat } \\
\text { tanıyor mu? }\end{array}$ & $\mathbf{x}$ & $\mathbf{x}$ & $\mathbf{x}$ & $\mathbf{x}$ & $\mathbf{x}$ \\
\hline $\begin{array}{l}\text { Etkinlik günlük hayattaki olaylardan } \\
\text { uyarlanarak kurgulanmıs mı? }\end{array}$ & $\mathbf{x}$ & $\mathbf{x}$ & $\mathbf{x}$ & $\mathbf{x}$ & $\mathbf{x}$ \\
\hline $\begin{array}{l}\text { Etkinlik önceki öğrenmelerle iliş ki kurmaya } \\
\text { yardımcı olabiliyor mu? }\end{array}$ & $\mathbf{x}$ & $\mathbf{x}$ & $\mathbf{x}$ & $\mathbf{x}$ & $\mathbf{x}$ \\
\hline $\begin{array}{l}\text { Etkinlik öğrencinin fiziksel ve zihinsel olarak } \\
\text { katıllımnı sağlıyor mu? }\end{array}$ & $\mathbf{x}$ & $\mathbf{x}$ & $\mathbf{x}$ & $\mathbf{x}$ & $\mathbf{x}$ \\
\hline Etkinlik öğrencilerin ilgis ini çekebiliyor mu? & $\mathbf{x}$ & $\mathbf{x}$ & $\mathbf{x}$ & $\mathbf{x}$ & $\mathbf{x}$ \\
\hline $\begin{array}{l}\text { Etkinlik hedef grubun bilişsel özelliklerine } \\
\text { uygun mu? }\end{array}$ & $\mathbf{x}$ & $\mathbf{x}$ & $\mathbf{x}$ & $\mathbf{x}$ & $\mathbf{x}$ \\
\hline \multicolumn{6}{|l|}{ Isslevsellik Boyutu } \\
\hline $\begin{array}{l}\text { Etkinlik ilgili hedeflere ulaşmayı sağlayacak } \\
\text { nitelikte mi? }\end{array}$ & $\mathbf{x}$ & $\mathbf{x}$ & $\mathbf{x}$ & $\mathbf{x}$ & $\mathbf{x}$ \\
\hline $\begin{array}{l}\text { Etkinlik kapsaminda kullanilan malzemeler } \\
\text { tekrar kullanıma uygun mu? }\end{array}$ & $\mathbf{x}$ & $\mathbf{x}$ & $\mathbf{x}$ & $\mathbf{x}$ & $\mathbf{x}$ \\
\hline $\begin{array}{l}\text { Etkinlik öğrencinin bağıms ız kullanımına } \\
\text { firsat tanıyabilecek nitelikte mi? }\end{array}$ & $\mathbf{x}$ & $\mathbf{x}$ & $\mathbf{x}$ & $\mathbf{x}$ & $\mathbf{x}$ \\
\hline $\begin{array}{l}\text { Etkinlik bireysel farkllıklara göre } \\
\text { uyarlanabilme özelliğine sahip mi? }\end{array}$ & $\mathbf{x}$ & $\mathbf{x}$ & $\mathbf{x}$ & $\mathbf{x}$ & $\mathbf{x}$ \\
\hline \multicolumn{6}{|l|}{ Kullanışlılık Boyutu } \\
\hline Etkinlik için planlanan zaman yeterli mi? & $\mathbf{x}$ & $\mathbf{x}$ & $\mathbf{x}$ & $\mathbf{x}$ & $\mathbf{x}$ \\
\hline $\begin{array}{l}\text { Etkinlikte kullanılan malzemeler maliyet } \\
\text { açıs mdan ekonomik mi? }\end{array}$ & $\mathbf{x}$ & $\mathbf{x}$ & $\mathbf{x}$ & $\mathbf{x}$ & $\mathbf{x}$ \\
\hline $\begin{array}{l}\text { Etkinlikte kullanılan malzemeler kolay } \\
\text { ulaşıllabilir nitelikte mi? }\end{array}$ & $\mathbf{x}$ & $\mathbf{x}$ & $\mathbf{x}$ & $\mathbf{x}$ & $\mathbf{x}$ \\
\hline $\begin{array}{l}\text { Etkinlikte kullanilan malzemeler kolay } \\
\text { kullanılabilir nitelikte mi? }\end{array}$ & $\mathbf{x}$ & $\mathbf{x}$ & $\mathbf{x}$ & $\mathbf{x}$ & $\mathbf{x}$ \\
\hline $\begin{array}{l}\text { Etkinlik öğrencinin güven liğini ön planda } \\
\text { tutuyor mu? }\end{array}$ & $\mathbf{x}$ & $\mathbf{x}$ & $\mathbf{x}$ & $\mathbf{x}$ & $\mathbf{x}$ \\
\hline
\end{tabular}

Tablo 4'teki verilere göre birinci ve üçüncü etkinliğin ön bilgileri test edemediğine karar verilmiştir. Öğretme boyutunda ise etkinlik öncesi hazırlık sorularının etkinliğe ilişkin farkındalık oluşturduğu, etkinlik malzemelerinin tanıtımı için yeterli zaman verildiği ve etkinliklerin planlanan konuya uygun olduğu tespit edilmiştir. Öğrenme boyutunda ise etkinliğin farklı duyuların kullanımına olarak sağladığı, etkinliğin günlük hayattaki olaylardan uyarlandığı, önceki öğrenmelerle ilişkili olduğu, fiziksel ve zihinsel olarak öğrencileri sürece çekebildiği ve öğrencilerin bilişsel özelliklerine uygun olduğu tespit edilmiştir. İşlevsellik boyutunda ise etkinliğin hedeflere uygun olduğu, etkinlik malzemelerinin tekrar kullanıma uygun olduğu, öğrencilerin bağımsız kullanımına olanak sağladığı ve bireysel farklılıklara göre uyarlanabilir olduğu tespit edilmiştir. Kullanışlılık boyutunda ise etkinlik için planlanan zamanın yeterli olduğu, etkinlik malzemelerinin ekonomik ve ergonomik olduğu, etkinlik malzemelerinin kolay kullanılabilir olduğu ve öğrencilerin güvenliğini ön planda tutabildiği tespit edilmiştir.

Tablo 4'te yer alan boyutlardan gerçekleşme durumlarına yönelik bilgilere aşağı da yer verilmiştir.

Ögretim Boyutu

"Öğretim boyutunda yer alan sorular ön bilgileri test etmeye uygun mudur?" sorusuna yönelik olarak DBP'de yer alan ve Şekil 2'de siyahla işaretlenmiş bölgede öğretmenin bir önceki derste öğrendikleri kavramlarla ilgili öğrencilerin ön bilgilerini açığa çıkarmasını istemektedir. Yönergeye göre ders işlenişinde öğretmenin ön bilgileri yokladığı ve öğrencilerin buna yönelik cevaplar verdiği belirlenmiştir:

Öğretmen: "Is1 iletkeni görmüştük, 1s1 yalıtkan1 görmüştük, 1S1 yalıtımını görmüştük değil mi? Şimdi bana 1s1 iletkeninin ne olduğunu kim söyleyebilir?"

Ö3: "Isıyı daha iyi iletendir."

Öğretmen: "Evet, 1sıyı iyi iletebilen maddelere 1sı iletkeni maddeler denir. Peki, 1s1 yalıtkanı nedir?"

Ö7: "Isıyı iyi iletemeyen maddelere denir tabiki."

\section{Dersin İșlenişi}

- Calışma Yaprağa 3 ve 4'dekl etkinilik için ögrencileri görme yetersizlikleri apsindan heterojen bir yapı olușturacak șekilde iki gruba ay̧umı

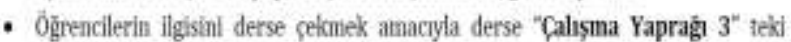
etkinilik düzeneğgini hazırlayarak ve yaplacak etkinligi oğrencilere anlatarak derse baslaysmaz.

- Deney düzeneklerini hazurlayp suları ilk scakliklarm älçīp soğunaya burakarak derse aşağidaki sorularla devam ediniz.

- On bilgileri harekete geçirmek için bir önceki derste ögrenillen is illetkeni ve yalıtkam kawramlanm sorgulayıız ve gerekli ise tekrar ediniz.

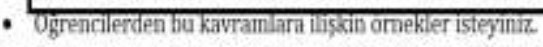

- Sorı-cevap ve beyin firtunasi tekniğini kullanarak maddenin ısyla ulan ilișkisine

Şekil 2. Ön bilgileri test etmeye yönelik yönerge

"Etkinlik ve kullanılacak malzemeler için verilen zaman yeterli mi?" sorusuna yönelik olarak DBP'de yer alan ve Şekil 3 'te siyahla işaretlenmiş bölgede öğretmen tarafindan her bir öğrencinin materyalleri inceletmesi ve tanımalarının sağlanmasını istenmektedir. Yönergeye göre etkinlik öncesi dağıtılan materyaller için öğretmenin tanımaları ve etkinliği gerçekleştirmek için yeterli süre verdiği belirlenmiştir:

Öğretmen: "Önünüze 1s1 yalıtım malzemesi oluşturabileceğiniz bir sürü madde bıraktım. İnceleyin bakalım ne önünüzdekiler.”

Ö7: "Kum"

Ö5: "Sünger"

Öğretmen: "İnceledin mi hepsini Ö2? İncelediysen şimdi bunları kullan ve 1s1 yalıtımı sağlayabileceğin bir model oluştur bakalım. Oluşturduğunda söyle etkinlik yapman için sıcak su dolduracağım." Ö2: "Tamam öğretmenim." 
Yaklaşık 5-7 dakika beklenir. Ve her bir öğrencinin etkinliği gerçekleştirmeye başlamadan önce konuşan termometre ile ölçüm alması sağlanır. Sonra düzenek tamamen kapatılır ve yaklaşık 10 dakika beklenir.

Öğretmen: "ilk sıcaklığı ölçmüştük şimdi kavanozların ağzını açacağız ve ölçüm yapacaksınız."

\section{Uygulama Yồnergesi

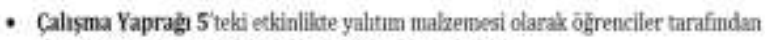 secilmeyen malzuneder olursa onlañ da siz demeginiz. \\ - Oxreaclere bu ders kapsaminda gectrilen is yaltum imabemelerimin her biriai

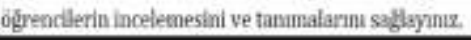 \\ Dersin ișleniş̧

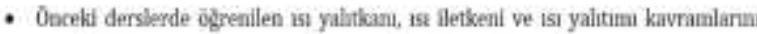

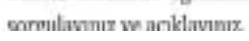

Şekil 3. Uygun zamana yönelik yönerge

\section{Öğrenme Boyutu}

"Etkinlik farklı duyu organlarına hitap ediyor mu?" sorusuna yönelik olarak etkinlikte konuşan termometrenin kullanılması ve etkinlikler esnasında materyallere dokunarak etkinlikleri gerçekleştirmelerinin sağlanması farklı duyu organlarına hitap edildiğini göstermektedir (Şekil 4).

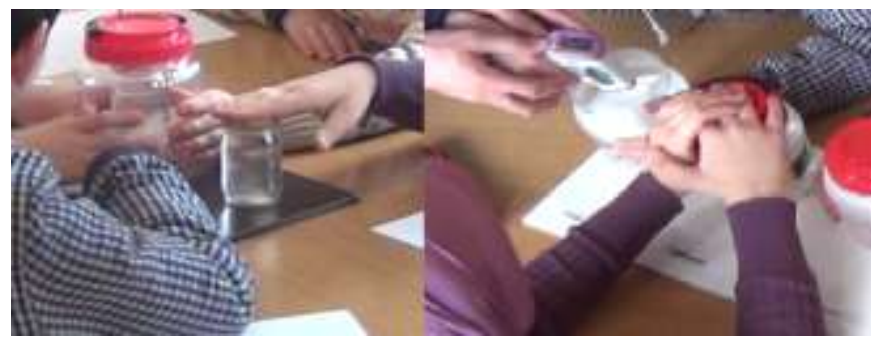

Şekil 4. Etkinlik ve materyallerde farklı duyu organlarının kullanılması

"Etkinlikler öğrencilerin ilgisini çekebiliyor mu?" sorusuna yönelik olarak Şekil 4'te kullanılan materyallerin ögrencilerin ilgisine de arttırdığı ve etkinliklere gönüllü olarak katıldığını göstermektedir:

Ö6: "Hocam şunu ben açayım. Açayım mı?"

Öğretmen: "Şimdi hangi bardak var?"

Ö4: "Karton bardak var."

Ö5: "Bunu da bende açayım."

Ö7: "Ben ölçeyim mi?"

\section{İslevsellik Boyutu}

"Etkinlik öğrencinin bağımsız kullanımına firsat tanıyabilecek nitelikte mi?" sorusuna yönelik olarak gerek etkinlik kâğıtlarının öğrenci yetersizlikleri dikkate alınarak dağıtılması (Şekil 5) gerekse etkinlikte sesli ve dokunsal materyallerin kullanılması (Şekil 4) öğrencilerin bağımsız etkinlik yapmasını destekler niteliktedir. Ayrıca bu belirtilen durumlar işlevsellik boyutunda "Etkinlik bireysel farklılıklara göre uyarlanabilme özelliğine sahip mi?" sorusuna da cevap vermektedir.

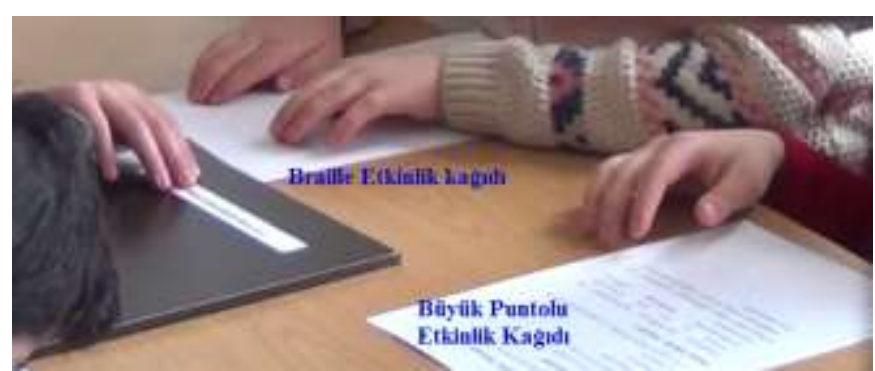

Şekil 5. Braille ve büyük puntolu etkinlik kâğıdı

\section{Kullanışlılık Boyutu}

"Etkinlik için planlanan zaman yeterli mi?" sorusuna yönelik olarak DBP'de verilen sürelerde (Şekil 6) öğretimin gerçekleştirildi belirlenmiştir. Bu nedenle etkinlikler için verilen sürelerin yeterli olduğu tespit edilmiştir.

\section{Ders Bilgi Paketi - III}

\section{Konu: Yalıtım ve Yalıtım Malzemeleri}

Kazanım: 6.6.1.4. Alternatif ısı yahtım malzemeleri geliştirir.

Süre: $40+40 \mathrm{dk}$.

Şekil 6. DBP'de yer alan süre

"Etkinlikte kullanılan materyaller maliyet açısından ekonomik mi?" sorusuna yönelik olarak sesli termometrenin maliyetinin 80-100 tl arasında değiştiğinden dolayı kısmen ekonomik olduğu söylenebilir. Fakat etkinliklere bütüncül olarak bakıldığında etkinliklerde kullanılan materyallerin günlük hayatta kolaylıkla çok cüzi bir miktara elde edilebileceği ve bu nedenle etkinlikte kullanılan materyallerin maliyet açısından ekonomik olduğu belirlenmiştir.

\section{Sonuç, Tartışma ve Öneriler}

$\mathrm{Bu}$ çalışmada görme yetersizliği olan öğrencilerin fen öğrenmeleri önündeki engelleri en aza indirmek amaciyla farklılaştırılmış öğretim materyalleri ve etkinlikleriyle fen kavramlarının öğretimi yapılmış ve bu etkinlik ve materyallerin verimliliği incelenmiştir. Sonuç olarak hazırlanan etkinliler ve materyallerin öğretim, öğrenme, işlevsellik ve kullanışlılık boyutlarının alt basamaklarını karşılandığı fakat Etkinlik 1 ve Etkinlik 4'ün formatına uygun olmadığından dolayı bu etkinliklerin ön bilgileri test etmediği tespit edilmiştir. Görme yetersizliği olan öğrencilere uyarlanarak hazırlanan kullanışlı ve işlevsel etkinlik ve materyallerle öğrencilere fen kavramlarının öğretimi sağlanabilir. Ayrıca Okcu ve Sözbilir (2019)'in belirtmiş olduğu gibi az gören öğrencilerin ise öncelikle görme duyusundan yararlanmalarını sağlayacak öğretim yöntemleri kullanılabilir.

Tasarım modelinde yer alan etkinliklerin FEGFEDB'te yer alan öğretim, öğrenme, işlevsellik ve kullanışlılık boyutlarındaki analiz verilerine göre etkinliklerin büyük çoğunluğu belirtilen boyutlardaki ihtiyaçları karşılamıştır. Öğretim boyutunda bazı konu ve kavramların öğrenciler için yeni olması öğrencilerin ön bilgilerini harekete geçirmeyi imkânsız kılabilmektedir (Campbell, Schwier ve Kenny, 2006). Görme yetersizliği olan öğrenciler arasında; sahip oldukları görme engelinin düzeyi ve ilave bir engele sahip olup olmama durumu, eğitim firsatlarından yararlanabilme durumu, ailenin sosyo-ekonomik düzeyi ve eğitime bakış 
açısı gibi birçok sebepten kaynaklanan bireysel farklılıklar bulunmaktadır. Bu farklılıklar aynı yaș ve sınıf düzeyindeki öğrencilere verilecek eğitimi de farklılaştırmayı gerekli kılmaktadır (Heward, Alber-Morgan ve Konrad, 2017). Bu nedenle çalışmada yapılan uyarlamaların görme yetersizliği olan öğrencilerin öğretimlerini destekleyeceği düşünülmektedir.

Görme yetersizliği olan öğrenciler görme duyusu dışında, bilgiye erişim amaciyla daha çok işitme, dokunma, koklama ve tatma duyularını kullanmaktadırlar (Demir ve Şen, 2009). Sahip olunan görme yetersizliği ve görme yetersizliğine bağli olarak değişen öğrenme stilleri sebebiyle, görme yetersizliği olan bireylerin öncelikle eğitimsel ihtiyaçları belirlenebilir; bireysel farklılıkları dikkate alınabilir (Rosenblum ve erzberg, 2011; Sözbilir, Zorluoğlu ve Kızılaslan, 2019; Şafak, 2012; ) ve eğitim süreci yeniden yapılandırılabilir. Özel eğitime muhtaç olan görme yetersizliği olan öğrenciler için bu yapılandırma 'bireyselleştirilmiş öğretim programı' (Cavkaytar ve Diken, 2012) ile gerçekleştirilebilir. Çalışma kapsamında hazırlanan DBP'leri öğrencilerin bireysel ihtiyaçları dikkate alındığından dolayı değerlendirme boyutlarının hemen hemen hepsinin karşılandığı düşünülmektedir.

Görme yetersizliği olan öğrencilere yönelik araç-gereç ve materyal seçimi ile uygun öğretim teknik, yöntem ve stratejilerin rahatlıkla kullanılabilmesi amacıyla, her eğitimöğretim kademesinde ve türünde kullanılabilen öğretim tasarımı modellerinden (Akakandelwa ve Munsanje, 2012) de yararlanılabilir. Görme yetersizliği olan ögrencilerin eğitim süreci içinde kavramsal anlamda öğrenme güçlüğü çektikleri fen bilimleri dersinde yer alan bazı öğrenme alanlarının öğretiminde de bu öğretim tasarımı modellerinden yararlanılabilir. Etkinliklerin bireysel farklılıklara göre uyarlanabilme özelliğine sahip olması ve etkinlik için planlanan zamanın yeterli olması çoğu eğitimcinin görme engelli öğrencilerin eğitiminde karşılaştıkları önemli sorunların (Healy ve Fernandes, 2011) üstesinden geldiği tespit edilmiştir.

Sonuç olarak görme yetersizliği olan öğrencilerin fen dersi programına güvenli ve tam olarak erişebilmeleri için Rosenblum ve Herzberg (2011)'in belirtmiş olduğu bazı uyarlamalar yapılabilir. Bu uyarlamalar bizim 'Madde ve Isı' ünitesi için belirlediğimiz materyal tasarlama kriterleri ile uyuşmaktadır. Ders yılı içerisinde müfredat, hedefler ve içerik görme yetersizliği olan öğrencilerin ihtiyaçları doğrultusunda düzenlenebilir. Öğretim materyallerin nasıl erişilebilir hale getirileceğini belirlerken öğrencilerin bireysel görsel ihtiyaçları (Kızılaslan ve Zorluoğlu, 2019; Zhou, Parker, Smith ve Griffin-Shirley, 2011) dikkate alınabilir. Fen öğretim malzeme veya materyalleri Freeland, Emerson, Curtis ve Fogarty (2010)'in belirtmiş olduğu ölçüm cihazları, çizelgeleri, okuma ekipmanı içerebilir. Görme bozukluğu olan öğrenciler, ortamları hakkında bilgi edinmek için dokunsal ve kinestetik girdileri kullanmaktadırlar. Sınıflarda kullanılan görsel materyallerin, görev için gerekli görsel becerilere sahip olmayan öğrenciler tarafindan kullanılması için uyarlanabilir. Grafikler, modeller, haritalar ve grafikler dokunma hissini kullanarak 'okunabiliyorsa' (Heward, 2000), görme yetersizliği olan öğrenciler için daha fazla eğitim değerine sahip olacağ 1 düşünülmektedir. Bu küçük çaplı araştırmanın sonuçlarına dayanarak, görme yetersizliği olan öğrencilerin fen eğitimi sisteminin bir parçası olmaya devam etmesine yardımcı olmak için ne gerekiyorsa sağlanabilir. Ayrıca bu çalışmada belirtilen deneyimlerden, görme yetersizliği olan öğrencilerin öğrenmekte zorlandıkları fen alanlarını keşfetmeye başlamaları için yararlanılabilir.

\section{Tesekkür}

Bu çalışma 114K725 no'lu TÜBİTAK projesi kapsamında finanse edilmiştir. $\mathrm{Bu}$ çalışmaya gönüllü katılan öğretmenlere, öğrencilere ve TÜBİTAK'a teşekkür ederiz.

\section{Kaynakça}

Akakandelwa, A. ve Munsanje, J. (2012). Provision of learning and teaching materials for pupils with visual impairment: Results from a national survey in Zambia. British Journal of Visual Impairment, 30, 42-49.

Ayas, A., Çepni, S. ve Akdeniz, A. R. (1993). Development of the Turkish secondary science curriculum. Science Education, 77(4), 433-440.

Bailey, B. R. ve Wning, J. D. (1994). Using visual accents to enhance attending to communication symbols for students with severe multiple disabilities. Re:View, 26(3), 101-118.

Bandyopadhyay, S. ve Rathod, B. B. (2017). The sound and feel of titrations: a smartphone aid for color-blind and visually impaired students. Journal of Chemical Education, 94(7), 946-949.

Bishop, V. E. ve Barraga, N. C. (2004). Teaching visually impaired children. Springfield: Charles C Thomas.

Bundsgaard, J. ve Hansen, T. (2011). Evaluation of learning materials. Journal of Learning Design, 4(4), 31-44.

Bülbül, M. Ş. ve Eryılmaz, A. (2012). Görme engelli öğrenciler için fizik ders araçları. Ankara: Murat Kitapevi.

Bülbül, M. Ş., Garip, B. ve Özdemir, Ö. F. (2017). Using a force concept inventory test with visually impaired and blind students. European Journal of Physics Education, 6(3), 20-31.

Campbell, K., Schwier, R. A. ve Kenny, R. F. (2006). Conversation as inquiry: A conversation with instructional designers. Journal of Learning Design, 1(3), 1-18.

Cavkaytar, A. ve Diken, İ. (2012). Özel eğitim 1- özel eğitim ve özel eğitim gerektirenler (1.bask1). Ankara: Vize Basin Yayın.

Cox, P. R. ve Dykes, M. K. (2001). Effective classroom adaptations for students with visual impairments. Teaching Exceptional Children, 33(6), 68-74.

Creswell, J.W. (2007). Qualitative inquiry and research design: Choosing among five traditions (Second edition). London: Sage.

Çakmak, S., Karakoç, T., Şafak, P. ve Kan, A. (2013, Temmuz). Awareness of students with low vision on their present level of visual acuities. 8th ICEVI European Conferenceon the Education and Rehabilitation of People with Visual Impairment, ICEVI Europe kongresinde sunulan sözlü bildiri, İstanbul. 
Demir, T. ve Şen, Ü. (2009). Görme engelli öğrencilerin çeşitli değişkenler açısından öğrenme stilleri üzerine bir araştırma. The Journal of International Social Research, 2(8), 154-161.

Fantin, D., Sutton, M., Daumann, L. J. ve Fischer, K. F. (2016). Evaluation of existing and new periodic tables of the elements for the chemistry education of blind students. Journal of Chemical Education, 93(6), 10391048.

Freeland, A. L., Emerson, R. W., Curtis, A. B. ve Fogarty, K. (2010). Exploring the relationship between access technology and standardized test scores for youths with visual impairments: Secondary analysis of the national longitudinal transition study. Journal of Visual Impairment \& Blindness, 104, 170-182.

Glesne, C. (2013). Nitel araştırmaya giriş. Ankara 2013.

Gürsel, O. (2012). Görme yetersizliği olan ögrrenciler. İ. H. Diken (Ed.). Özel eğitime gereksinimi olan öğrenciler ve özel eğitim içinde (ss. 217-249). Ankara: Pegem Akademi.

Hasper, E., Windhorst, R. A., Hedgpeth, T., Van Tuyl, L., Gonzales, A., Martinez, B., ... ve Baluch, D. P. (2015). Methods for creating and evaluating 3D tactile images to teach STEM courses to the visually impaired. Journal of College Science Teaching, 44(6), 92-99.

Healy, L. ve Fernandes, S. H. A. A. (2011). The role of gestures in the mathematical practices of those who do not see with their eyes. Educational Studies in Mathematics, 77, 157-174.

Heward, W. L., Alber-Morgan, S. R. ve Konrad, M. (2017). Exceptional children an introduction to special education (11th ed.). Boston, MA: Pearson.

Hritcko, T. (1989). Assessment of children with low vision. Editor: Jose R. T. Understanding Low Vision. NY: AFB Press.

Kalayc1, N. (2001). İki boyutlu görsel öğrenme ve öğretme araçlari. H. İ. Yalın (Ed.). Öğretim teknolojileri ve materyal geliştirme içinde (ss.67-80). Ankara, Nobel Yayın Dağıtım.

Kargın, T. (2012). Özel ĕgitime gereksinimi olan öğrenciler ve özel eğitim. Ankara: Pegem Akademi.

Kandaz, Ş. (2004). Görmezlerin fizik dersine bakış açıları, fizik ögrenmelerindeki zorluklar ve görmezlerle fizik deney uygulamalart (Yüksek lisans tezi). Yükseköğretim Kurulu Ulusal Tez Merkezi'nden edinilmiştir. (Tez No. 148750)

Kizılaslan, A. (2019). An instructional design to teaching science concepts to visually impaired students. Science Education International, 30(1), 56-64.

Kızılaslan, A. ve Sözbilir, M. (2017). Görme yetersizliği olan öğrencilere için tasarlanan etkinliğin bilimsel süreç becerilerine göre analizi. SDU International Journal of Educational Studies, 4(2), 86-95.

Kızılaslan, A., Sözbilir, M., \& Zorluoğlu, S. L. (2019). Making Science Accessible to Students with Visual Impairments: Insulation-Materials Investigation. Journal of Chemical Education, 96(7), 1383-1388.
Kizılaslan, A., \& Zorluoğlu, S. L. (2019). contribution of activities developed for visually impaired students to scientific process skills. European Journal of Physics Education, 10(1), 49-58.

Levack, N., Stone, G. ve Bishop, V. (1991). Low vision: A resource guide with adaptations for students with visual impairments. Austin: Texas School for the Blind and Visually Impaired.

Mann, C. (2006). Educational placement options for blind and visually impaired students: A literature review (SESRC Document No. 06-01-2202). Social \& Economic Sciences Research Center-Puget Sound Division. Olympia, Washington: Washington State Institute for Public Policy.

Nepomuceno, G. M., Decker, D. M., Shaw, J. D., Boyes, L., Tantillo, D. J. ve Wedler, H. B. (2016). The value of safety and practicality: Recommendations for training disabled students in the sciences with a focus on blind and visually impaired students in chemistry laboratories. Journal of Chemical Health and Safety, 23(1), 5-11.

Okcu, B. ve Sözbilir, M. (2019). Designing a bulb to teach electric circuits to visually impaired students. The Physics Teacher, 57(2), 99-101.

Özsoy, Y., Özyürek, M. ve Eripek, S. (2002). Özel eğitime muhtaç çocuklar, özel eğitime giriş. Ankara: Karatepe Yayınları.

Özyürek, M. (1998). Görme engelliler. S. Eripek (Ed.), Özel eğitim içinde (s.126-152). Eskişehir: Anadolu Üniversitesi Açık Öğretim Fakültesi.

Özyürek, M. (2000). Görme özürlülerin eğitimi. Ankara: Körler Federasyonu Yayını.

Rosenblum, L. P. ve Herzberg, T. (2011). Accuracy and techniques in the preparation of mathematics worksheets for tactile learners. Journal of Visual Impairment \& Blindness, 105, 402-413

Rule, A., Stefanich, G.P., Boody, R.M. ve Peiffer, B. (2011). Impact of adaptive materials on teachers and their students with visual impairments in secondary science and mathematics classes. International Journal of Science Education, 33(6), 865-887.

Smith, D. W. ve Kelley, P. (2007). A survey of assistive technology and teacher preparation programs for individuals with visual impairments. Journal of Visual Impairment \& Blindness, 101(7), 429-433.

Sözbilir, M., Zorluoğlu, S. L., \& Kizılaslan, A. (2019). Görme yetersizliği olan öğrencilere yönelik geliştirilen fen etkinliklerin bilimsel süreç becerileri öğrenimine etkisi. Cumhuriyet Uluslararast Eğitim Dergisi, 8(1), 172-192.

Şafak, P. (2012). Bireyselleştirilmiş eğitim programı. A. Ataman (Ed.), Temel eğitim ögrretmenleri için kaynaştırma uygulamaları ve özel ĕgitim içinde (s. 8399). Ankara: Vize Yayıncılık.

Topor, I. R. ve Erin, J. N. (2000). Educational assessment of vision function in infants and children. Barbara Silverstone, Mary Ann Lang, Bruce Rosenthal \& Eleanor 
E. Faye (Eds.), The lighthouse handbook on vision impairment anda rehabilitation içinde (s. 821-831). New York: Oxford Univesity.

Tuncer, T. (2005). Görme yetersizliği olan çocuklar. A. Ataman (Ed.), Özel gereksinimli çocuklar ve özel eğitime giriş içinde (s. 291-309). Ankara: Gündüz.

Turnbull, A. P., Turnbull, H. R. ve Wehmeyer, M. (2007). Exceptional lives: Special education in todays schools (3rd ed.). Upper Saddle River, NJ: Merrill Prentice Hall.
Yin, R. K. (2013). Case study research: Design and methods (5. Bask1). Thousand Oaks, CA: Sage.

Zatta, M. C. ve Pullin, D.C. (2004). Education and alternate assessment for students with significant cognitive disabilities: Implications for educators. Education Policy Analysis Archives, 12(16), 1-27.

Zhou, L., Parker, A. T., Smith, D. W. ve Griffin-Shirley, N. (2011). Assistive technology for students with visual impairments: Challenges and needs in teachers' preparation programs and practice. Journal of Visual Impairment \& Blindness, 105, 197-210. 
31 Kızılaslan, A., Zorluoğlu S. L., Sözbilir, M. \& Teke, D. / Anemon Muş Alparslan Üniversitesi Sosyal Bilimler Dergisi, 2020 8(1) 19-32

EK 1.

Örnek Ders Bilgi Paketi

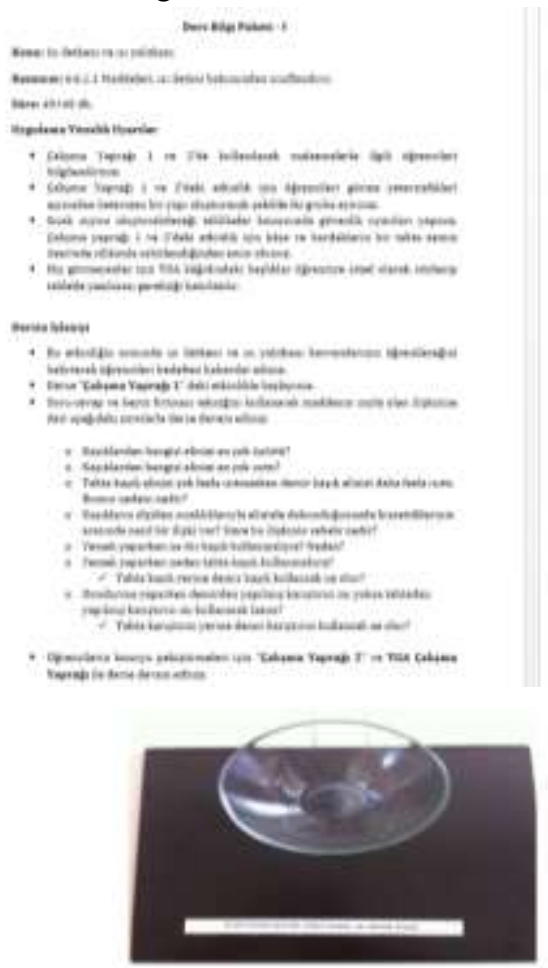

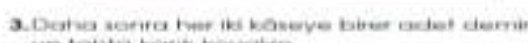
ve torte basis bovalin.

4. Op dobika sama net Lovedebl kagitionen

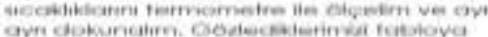
vokines.

\section{Simdi asogidaki soruton cevaplayalim}

1.Kogibardan hangisl eînizi ołatto?

2. Kogukiardan hangisi eirrizi istes

3. Kayiban elinizi en az istandion en çok sitona dogru smolayne.

4. Koykikan merkikikam on at olandan en gok clonta diogru srotaninis.

Simdi asağudakl sorulan cevaplayalim

1. Hiangi bordak elinizl daha gok isithit Neden?

2. Hangi bardak eirnizi daha en at isithe Neden?

3. Bardokian elinit en oz ustan en çok ston.

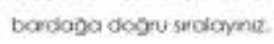

4. Tencere veya tava scksran ell yakmamas için hang onlemier airur: Neclen:

\section{Ehinilikten Çkardigima sonuç}

- Isi ycalitkara sizce ne domektir

- Is äelceri sirce ne cemektir

- Bir modde sin cok lyi hellyorso in yostion mair yoksas ietkeni midirs

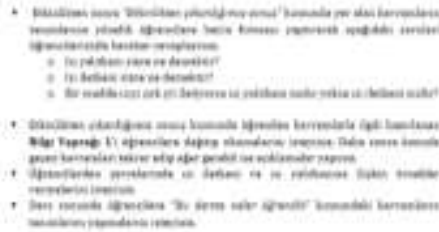

Cahsma Yaprağ 1

Esinlik: Hangi kapik ays daha az letir:

\section{Gerekdi Matzemeier}

- 2 adiet demi kapk

- 2 adel tanta bajk

- 2 adiot kose

- Sicak sir

- buazsu

- Konvan termometre, nomna termometre Haydi. Etikinlik Yapahm

1.Kopidann scokdikarin fermametre lie Oivelim ve ayn ayn dokunaim Godemiknimizi aqajudoki tablaya vaydedeim.

2. Heumdek kase odzeneoin hullonoim ye

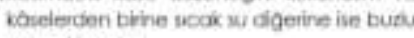
unvedeyeim

\begin{tabular}{|c|c|c|c|c|}
\hline \multirow[b]{2}{*}{$\begin{array}{l}\text { Kasik } \\
\text { Cosies }\end{array}$} & \multicolumn{2}{|c|}{ Deney Oncer } & \multicolumn{2}{|c|}{ Dener Sarmat } \\
\hline & sieakdik & $\begin{array}{l}\text { Dedicharak } \\
\text { Minsematerimiz }\end{array}$ & Sheokith & $\begin{array}{l}\text { Doflumarak } \\
\text { Hissetunierimir }\end{array}$ \\
\hline Demit & & & & \\
\hline Tahte & & & & \\
\hline
\end{tabular}

\section{Calisma Yapeogi 2}

Eblinilik: Cayi hangi badalsa fałmathame

\section{Gereka Malzemeler}

- I adel demir bardak

- I adiet kosat bardak.

- I adel carn bardak

- I adiat bople bardos

- Srcak com

Haydi, Etkinlik Yapalim

1.TGA kogidines tohmin et kimuna içine çay. dodation bardokfardon hangishin elrrist doha çok rsitocagirv tohvrin edeim.

2. Retimsekj dofeneo kuancrak bardibiam ter binine esit riktarda say ekeyefm.

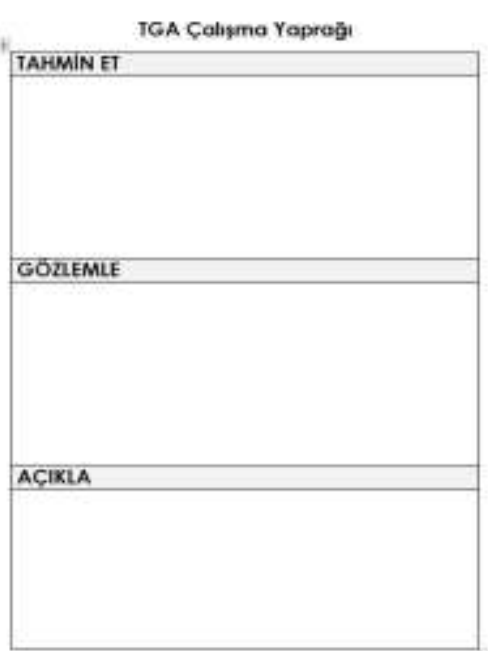

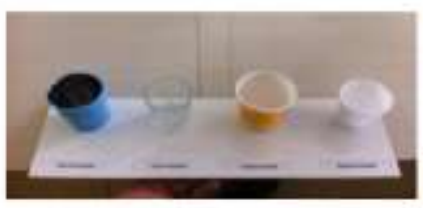

3.lçinde cay butmon bandakiara sratryia ikbook bardak, kbat bordak cami kardak ve demir bandaks debunam.

4.Konuson termometre le srasiyla whpoi bardak kagit bardok oam bardok we dernir bardok yozeylerin scolikiarm obcelim.

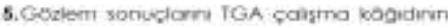
gozemie kssturia yatoim

6. Hangi bardagan dis yozerinin neden datra scoki oldugurw açbdayolm

\section{Bilgi Yaprogi 1}

Her madde ayni dereoede isiyn lietmez. Maddeler ssy iletmelerine göre s letkeni ve Is

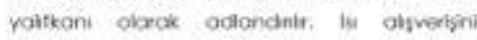
encellemeyen veyo ssy his seten modidelere isi lietkeni medde demir. Altin. almus bokit diuminyum demir ve çelik gibi metoller ism iy ileten mad deiere ernek olarok veriebulir, lsyn iy lietrreyen maddelese ist yaittkani maddeler denir. Flastik fahta. saman deri. elval ve parruk gbi maddeler wa yalikani moddelere crnek olarak weriebilt. 
EK 2.

Fen Etkinlik Gözlem Formu Etkinlik Değerlendirme Boyutu

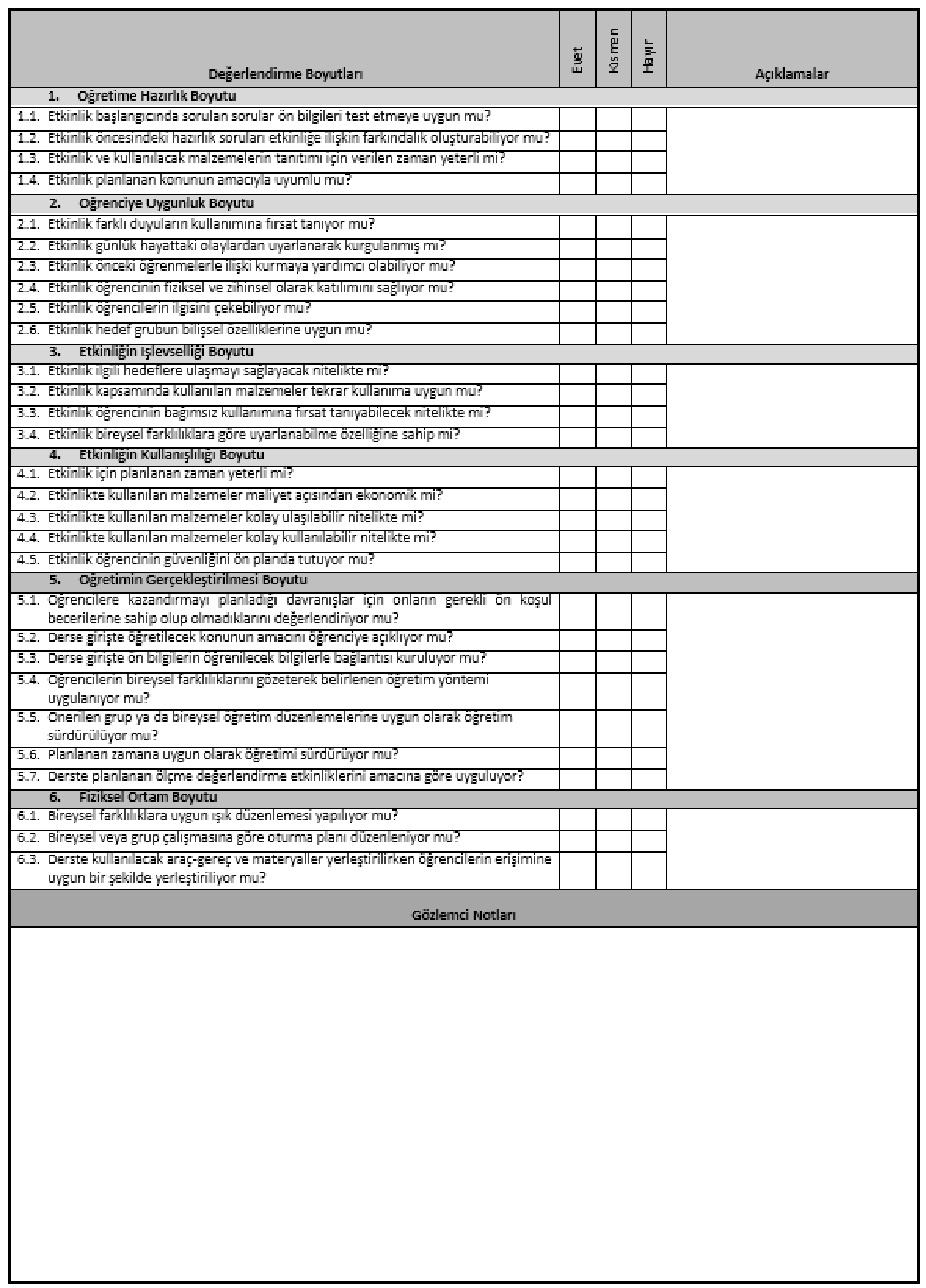

